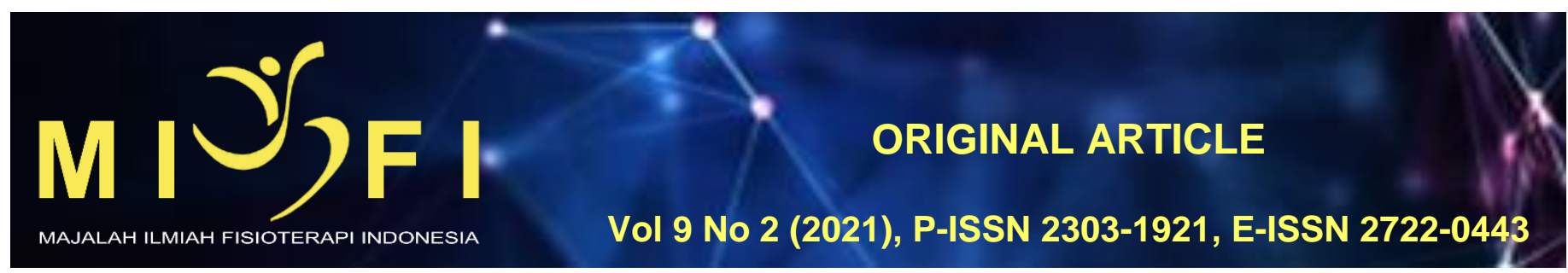

\title{
PENAMBAHAN CAWTHORNE COOKSEY EXERCISE PADA SENAM LANSIA MENURUNKAN RISIKO JATUH LANSIA DI KARANG LANSIA MELATI PUTIH JEMBRANA
}

\author{
I Gusti Ayu Putu Armayanthi ${ }^{1}$, Anak Ayu Nyoman Trisna Narta Dewi², Putu Ayu Sita Saraswati ${ }^{3}$, \\ I Made Muliarta ${ }^{4}$ \\ ${ }^{1}$ Program Studi Sarjana Fisioterapi Dan Profesi Fisioterapi, Universitas Udayana, Denpasar, Bali \\ 2,3Departemen Fisioterapi, Universitas Udayana, Denpasar, Bali \\ 4Departemen Fisiologi Keolahragaan, Universitas Udayana, Denpasar, Bali \\ armayantii@gmail.com
}

\begin{abstract}
ABSTRAK
Penuaan pada lansia akan menurunkan kemampuan fungsional lansia. Salah satu penuaan pada lansia adalah keseimbangan yang akan meningkatkan risiko jatuh lansia. Senam lansia merupakan salah satu intervensi yang dapat diberikan untuk menurunkan risiko dan masih ada komponen keseimbangan yang lain yang bisa ditingkatkan dengan latihan lain seperti Cawthorne Cooksey Exercise (CCE). Tujuan penelitian ini adakag untuk mengetahui penambahan Cawthorne Cooksey Exercise (CCE) pada senam lansia untuk menurunkan risiko jatuh pada lansia. Penelitian ini merupakan penelitian eksperimental dengan rancangan penelitian Pre and Post Test Two Group Desgin. Sampel dibagi menjadi 2 kelompok, masing-masing kelompok terdiri dari 12 responden. Teknik pengambilan sample menggunakan simple random sampling. Pengukuran risiko jatuh diukur menggunakan kuesioner Berg Balance Scale (BBS). Pemberian latihan pada kedua kelompok dilakukan selama 9 minggu. Dari analisis data menggunakan uji Paired sample $t$-test pada kelompok perlakuan dan kelompok kontrol didapatkan nilai $p$ sebesar $(p=0,000)$ dan uji independent sample $t$-test pada skor BBS sesudah penelitian didapatkan nilai $p$ sebesar $(p=0,02)$. Hasil penurunan risiko jatuh pada kelompok perlakuan yaitu dari 36,83 menjadi 43,17, sedangkan pada kelompok kontrol yaitu dari 35,83 menjadi 40,33. Berdasarkan hasil penelitian tersebut, maka dapat disimpulkan bahwa penambahan CCE pada senam lansia lebih efektif dalam menurunkan risiko jatuh dibandingkan senam lansia pada lansia di Karang Lansia Melati Putih Jembrana. Kata Kunci: Cawthorne Cooksey Exercise, senam lansia, risiko jatuh, lansia
\end{abstract}

\section{THE ADDITION OF CAWTHORNE COOKSEY EXERCISE ON ELDERLY EXERCISE/GYMNASTIC REDUCES RISK OF FALLS AMONG ELDERLY IN THE COMMUNITY OF KARANG LANSIA MELATI PUTIH JEMBRANA}

\begin{abstract}
Aging in the elderly will reduce the functional ability of the elderly and will increase the risk of falls. Elderly gymnastic is one of the possible interventions in order to reduce the elderly risk of falls and still possible to increase some components of balance by doing other exercises. This study aimed to identify the effect of adding Cawthorne Cooksey Exercise (CCE) to the elderly gymnastic in order to reduce the elderly risk of falls. This study was an experimental study with the Pre and Post Test Two Group Design that was conducted from January to March 2020. In obtaining the sample, this study used simple random sampling method in the elderly in Karang Lansia Melati Putih Jembrana. There were 24 elders participated as the study who were divided into two groups. The intervention group that was given CCE and elderly gymnastic, control group that was given the elderly gymnastic. The risk of falls was measured by Berg Balance Scale (BBS). The Paired sample t-test result showed that both of the groups obtained $p=0,000$ value which means that the elderly risk of fall was reduced by either adding CCE to elderly gymnastic. The results of risk reduction in the intervention group were from 36.83 to 45.50 , the control group that was from 35.83 to 40.33. Based on this result, it can be concluded that adding CCE in the elderly gymnastic is effective in reducing the elderly risk of falls than the elderly gymnastic among elderly community of Karang Lansia Melati Putih Jembrana.

Keywords: Cawthorne Cooksey Exercise, elderly exercise, risk of fall, elderly
\end{abstract}

\section{PENDAHULUAN}

Lanjut Usia (Lansia) merupakan fase hidup yang tidak bisa dihindari oleh setiap manusia. Lansia merupakan seseorang yang berusia lebih dari 60 tahun. ${ }^{1}$ Semakin bertambahnya usia sejalan dengan proses penuaan. Proses penuaan tersebut bisa terjadi secara cepat atau lambat. Jumlah lansia di Indonesia meningkat setiap tahunnya. Pada tahun 2019, persentase lansia mencapai 9.60 persen atau sekitar 25,64 juta orang dan diprediksi akan meningkat setiap tahunnya. ${ }^{2}$ Prediksi tersebut akan menyebabkan Indonesia termasuk negara berstruktur tua (ageing population). Ageing population merupakan salah satu tanda semakin tingginya rata-rata Usia Harapan Hidup (UHH). Usia Harapan Hidup yang tinggi merupakan salah satu indikator keberhasilan pembangunan nasional terutama di bidang kesehatan. ${ }^{3}$ Lansia mengalami penurunan fungsi tubuhnya yang disebabkan oleh proses penuaan. Penurunan fungsi tersebut akan menyebabkan lansia mengalami gangguan untuk beraktivitas. Salah satu perubahan pada lansia adalah pada sistem keseimbangan. Integritas sistem visual, vestibular, dan somatosensoris serta sistem muskuloskeletal dibutuhkan untuk 
keseimbangan. Pada lansia terjadi perubahan pada kedua sistem tersebut, sehingga akan menurunkan keseimbangan lansia dan meningkatkan risiko jatuh pada lansia. ${ }^{4}$ World Health Organization (WHO) melaporkan peningkatan kejadian jatuh terjadi sekitar $28-35 \%$ pada orang berusia di atas 65 tahun dan orang yang berusia lebih dari 70 tahun mengalami peningkatan sebesar $32-42 \% .{ }^{5}$ Cedera kepala, cedera jaringan lunak, dan fraktur merupakan akibat yang ditimbulkan oleh jatuh. 6

Salah satu upaya yang dapat dilakukan untuk mengatasi kejadian jatuh pada lansia adalah dengan melakukan aktivitas fisik yang teratur dan terprogram. Aktivitas fisik yang dapat diberikan kepada lansia tidak hanya mudah dan murah dilakukan, tetapi dapat membantu lansia dalam mencapai keseimbangan yang optimal sehingga risiko jatuh lansia menurun. Salah satu aktivitas fisik tersebut adalah senam lansia. Senam lansia merupakan sebuah aktivitas yang dilakukan oleh lansia menggunakan gerakan dan nada yang teratur, terarah dan terencana dengan tujuan meningkatkan kemampuan fungsional. ${ }^{7}$ Mekanisme pada senam lansia untuk menurunkan risiko jatuh dominan pada sistem muskuloskeletal, sedangkan keseimbangan yang baik membutuhkan integritas sistem sensoris dan muskuloskeletal. Senam lansia dapat dioptimalkan dengan latihan lain yaitu Cawthorne Cooksey Exercise (CCE) yang merupakan sebuah latihan rehabilitasi vestibular yang dapat dilakukan oleh lansia normal tanpa gangguan vestibuler. Program CCE ini mekanismenya dominan meningkatkan sistem sensoris (visual, vestibular, dan somatosensoris) yang akan meningkatkan stabilitas pandangan dan kontrol postural pada lansia, sehingga dapat menurunkan risiko jatuh pada lansia. ${ }^{8}$

\section{METODE}

Penelitian ini merupakan penelitian eksperimental dengan rancangan penelitian Pre and Post Test Two Group Design. Pada penelitian ini terdapat tiga variabel; variabel bebas adalah CCE dan senam lansia, sedangkan variabel terikat adalah risiko jatuh yang diukur dengan kuesioner BBS. Variabel yang dikontrol dalam penelitian ini adalah aktivitas fisik yang diukur menggunakan kuesioner Baecke Index. Penelitian ini dilakukan dari bulan Januari - Maret 2020.

Sampel pada penelitian ini adalah lansia di Karang Lansia Melati Putih Jembrana dengan pengambilan sampel secara simple random sampling yang telah memenuhi krtiteria inklusi dan eksklusi sebanyak 24 orang. Sampel dihitung menggunakan rumus Pocock, yang dibagi menjadi 2 kelompok yaitu 12 responden pada kelompok I (kelompok perlakuan dan 12 responden pada kelompok II (kelompok kontrol). Kelompok perlakuan mendapatkan pelatihan CCE dan senam lansia, sedangkan kelompok kontrol mendapat senam lansia Pemberian latihan dilakukan selama 9 minggu, dengan frekuensi 2 kali per minggu. Setiap latihan berdurasi 60-80 menit.

Kriteria inklusi : Berjenis kelamin laki-laki dan perempuan, berusia lebih dari 60 tahun, bersedia secara sukarela sebagai subjek penelitian dari awal sampai akhir penelitian dengan menandatangani informed consent bersedia sebagai sampel, memiliki nilai BBS dengan skor 0-40, dan belum pernah melakukan latihan CCE sebelumnya. Sedangkan kriteria eksklusi: memiliki gangguan mobilisasi berat, Mengalami lesi vestibular yang tidak stabil, mengidap penyakit Meniere. Data yang didapatkan dalam penelitian ini dianalisa menggunakan software Statistical Package for the Social Sciences (SPSS).

HASIL

Tabel 1. Distribusi Data Sampel Berdasarkan Jenis Kelamin

\begin{tabular}{ccccc}
\hline \multirow{2}{*}{ Jenis Kelamin } & \multicolumn{2}{c}{ Frekuensi } & \multicolumn{2}{c}{ Persen } \\
\cline { 2 - 5 } & Kelompok I & Kelompok II & Kelompok I & Kelompok II \\
\hline Laki-Laki & 2 & 1 & 16,7 & 8,3 \\
Perempuan & 10 & 11 & 83,3 & 91,7 \\
\hline
\end{tabular}

Tabel 1. menunjukkan responden dengan jenis kelamin laki-laki pada kelompok I yaitu 16,7\% (2 orang) dan pada kelompok II sebesar 8,3\% (1 orang). Responden dengan jenis kelamin perempuan pada kelompok I yaitu 83,3\% (10 orang) dan pada kelompok II sebesar $91,7 \%$ (11 orang).

Tabel 2. Rerata Data Sampel Berdasarkan Umur

\begin{tabular}{ccccc}
\hline \multirow{2}{*}{ Karakteristik } & \multicolumn{3}{c}{ Nilai rerata dan simpang baku } \\
\cline { 2 - 5 } & \multicolumn{2}{c}{ Kelompok Perlakuan } & \multicolumn{2}{c}{ Kelompok Kontrol } \\
\cline { 2 - 5 } Uerata & Simpang Baku & Rerata & Simpang Baku \\
\hline Umur & 69,17 & 3,298 & 67,50 & 2.939 \\
\hline
\end{tabular}

Tabel 2. menunjukkan responden pada kelompok I memiliki rerata umur 69,17 tahun dan pada kelompok II memiliki rerata umur 67,5 tahun.

Tabel 3. Distribusi Data Sampel Berdasarkan Aktivitas Fisik

\begin{tabular}{ccccc}
\hline \multirow{2}{*}{ Aktivitas Fisik (Indeks Baecke) } & \multicolumn{3}{c}{ Frekuensi } & \multicolumn{2}{c}{ Persen } \\
\cline { 2 - 5 } & Kelompok I & Kelompok II & Kelompok I & Kelompok II \\
\hline Rendah & 8 & 6 & 66,7 & 50 \\
Sedang & 4 & 6 & 33,3 & 50 \\
\hline
\end{tabular}

Tabel 3. menunjukkan bahwa responden pada kelompok I memiliki rerata aktivitas fisik rendah 66,7\% (8 orang) dan rerata aktivitas fisik sedang sebesar 33,3\% (4 orang). Pada kelompok II, responden yang memiliki rerata aktivitas fisik rendah yaitu sebesar $50 \%$ (6 orang) dan responden yang memiliki rerata aktivitas fisik sedang sebesar $50 \%$ (6 orang).

Tabel 4. Hasil Uji Normalitas dan Homogenitas 


\begin{tabular}{cccccc}
\hline \multirow{2}{*}{ Kelompok Data } & \multicolumn{4}{l}{ Uji Normalitas (Shapiro Wilk Test) } & \\
\cline { 2 - 5 } & \multicolumn{2}{c}{ Kelompok I } & \multicolumn{2}{c}{ Kelompok II } & Uji Homogenitas (Levene's Test) \\
\cline { 2 - 5 } & Rerata & $\mathrm{p}$ & Rerata & $\mathrm{p}$ & \\
\hline Pre Test & 35,50 & 0,23 & 35,8 & 0,19 & 0,43 \\
Post Test & 43,17 & 0,15 & 40,3 & 0,84 & 0,09 \\
\hline
\end{tabular}

Tabel 4. menunjukkan hasil uji normalitas dengan menggunakan Shapiro Wilk Test pada kelompok perlakuan sebelum perlakuan didapatkan nilai $p>0,05$ dan setelah latihan didapatkan nilai $p>0,05$. Hasil tersebut menunjukkan bahwa data pada penelitian ini berdistribusi normal. Uji homogenitas menggunakan Levene's Test yang menunjukkan data skor BBS sebelum perlakuan didapatkan nilai $p>0,05$. Hasil tersebut menunjukkan data bersifat homogen.

Tabel 5. Rerata Penurunan Skor BBS Sebelum dan Setelah Perlakuan pada Kelompok I dan Kelompok II

\begin{tabular}{ccccc}
\hline & Pre Test & Post Test & Simpang Baku & p \\
\cline { 2 - 5 } & Rerata & Rerata & & 1,16 \\
\hline Kelompok I & 35,50 & 43,17 & 0,000 \\
Kelompok II & 35,83 & 40,33 & 0,52 & 0,000 \\
\hline
\end{tabular}

Tabel 5. menunjukkan hasil beda rerata peningkatan Skor BBS dengan Paired Sample $T$-test sebelum dan sesudah pelatihan pada kelompok I dan kelompok II didapatkan nilai $p=0,000 \quad(p<0,05)$ yang menunjukkan ada perbedaan yang bermakna pada peningkatan Skor BBS sebelum dan sesudah diberikan perlakuan pada masingmasing kelompok.

Tabel 6. Uji Beda Hasil Selisih Peningkatan Skor Berg Balance Sccale Sebelum dan Sesudah Pelatihan pada Kedua Kelompok

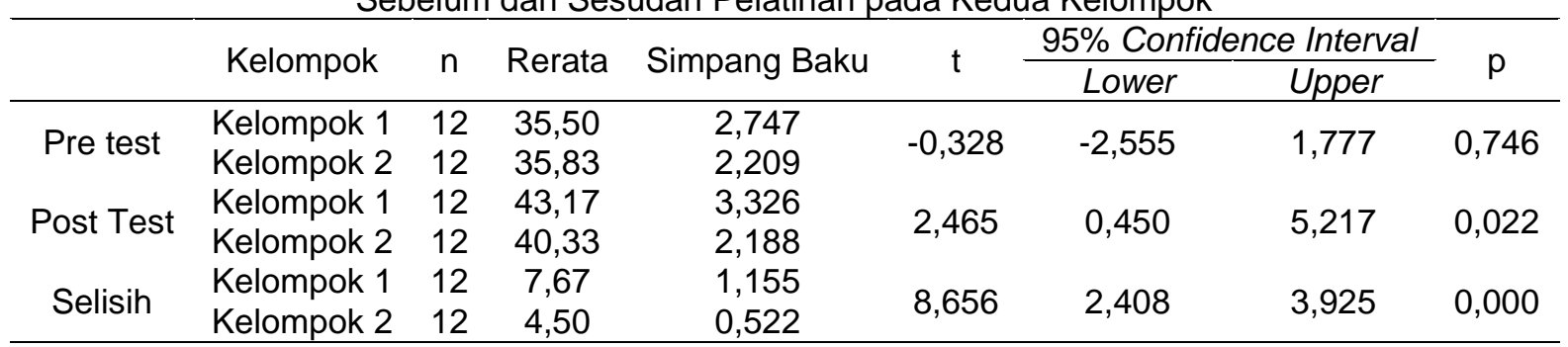

Tabel 6. memperlihatkan nilai $p=0,022(p<0,05)$ sesudah pelatihan yang artinya ada perbedaan yang bermakna antara kelompok perlakuan dan kelompok kontrol terhadap peningkatan skor BBS. Hal tersebut berarti bahwa penambahan CCE pada senam lansia lebih efekktif dibandingkan senam lansia untuk menurunkan risiko jatuh pada lansia.

\section{DISKUSI}

\section{Karakteristik Sampel}

Pada kelompok I memiliki rerata responden dengan jenis kelamin laki-laki yaitu 16,7\% (2 orang) dan pada kelompok II sebesar 8,3\% (1 orang). Rerata responden dengan jenis kelamin perempuan pada kelompok I yaitu sebesar $83,3 \%$ (10 orang) dan $91,7 \%$ ( 11 orang) pada kelompok II. Kejadian jatuh pada lansia perempuan lebih tinggi dibandingkan dengan lansia laki-laki. Hal tersebut diakibatkan oleh faktor aktivitas, kekuatan otot, faktor hormonal, psikologi dan antropometri yang berbeda. ${ }^{4}$

Berdasarkan rerata umur, responden pada kelompok I memiliki rerata umur 69,17 tahun dan pada kelompok II memiliki rerata umur 67,5 tahun. Usia berpengaruh dengan risiko jatuh dimana semakin meningkat usia seseorang maka mempunyai risiko 9 kali untuk mengalami kejadian jatuh. ${ }^{9}$ Berdasarkan aktivitas fisik menunjukkan subjek pada kelompok I memiliki rerata aktivitas fisik rendah $66,7 \%$ (8 orang) dan rerata aktivitas fisik sedang sebesar $33,3 \%$ (4 orang). Pada kelompok II, subjek yang memiliki rerata aktivitas fisik rendah yaitu sebesar $50 \%$ (6 orang) dan rerata aktivitas fisik sedang sebesar 50\% (6 orang). $85 \%$ tingginya risiko jatuh pada lansia disebabkan oleh lansia cenderung tidak aktif dalam aktivitas fisiknya. ${ }^{10}$

\section{Senam Lansia dapat Menurunkan Risiko Jatuh Lansia}

Uji paired sample $t$-test pada kelompok II yaitu didapatkan nilai $p<0,05$ yang menunjukkan bahwa ada perbedaan yang bermakna pada hasil pengukuran skor BBS sebelum dan sesudah pemberian senam lansia. Peningkatan skor BBS menunjukkan terjadinya penurunan risiko jatuh pada lansia di kelompok II.

Senam bugar lansia terutama latihan keseimbangan dan kekuatan yang merupakan salah satu senam aerobic low impact adalah salah satu intervensi yang dapat mengurangi jatuh pada lansia sehingga senam bugar lansia dijadikan sebagai program intervensi untuk pencegahan jatuh. Hal ini disebabkan karena senam mampu meningkatkan mobilitas, kekuatan, dan keseimbangan tubuh Senam lansia meningkatkan sistem muskuloskeletal. Peningkatan tersebut antara lain peningkatan kemampuan untuk meningkatkan respon otot postural. Selain itu terjadi juga peningkatan kemampuan ankle strategy, serta aktivasi otot hamstrings yang akan menyebabkan kemampuan yang baik untuk menyangga tubuh bagian atas, sehia akan menyebabkan peningkatan respon untuk mempertahankan postur saat berdiri tegak dan mengatur keseimbangan tubuh sehingga risiko jatuh menurun. ${ }^{11}$

Hasil pada penelitian ini didukung penelitian lain yang menyatakan senam lansia menurunkan risiko jatuh lansia yang signifikan sebesar $51,9 \%$. Pada senam lansia prinsipnya otot-otot tubuh secara general akan dipacu untuk 
bergerak. Gerakan-gerakan yang terpola dan terprogram akan memberikan respon adaptatif secara fisiologis pada sistem musculoskeletal. ${ }^{12}$

\section{Penambahan Cawthorne Cooksey Exercise pada Senam Lansia dapat Menurunkan Risiko Jatuh}

Uji statistik menunjukkan hasil rerata skor BBS pada kelompok I yang diberikan penambahan pelatihan CCE pada senam lansia mendapat skor pre test 35,83 dan meningkat saat post test menjadi 43,17 . Uji paired sample $t$-test yang digunakan untuk mengetahui peningkatan skor BBS pada kelompok kontrol antara sebelum dan sesudah penelitian menunjukkan $p=0,000(p>0,05)$ yang berarti adanya peningkatan skor BBS yang signifikan.

Pada lansia terjadi penuaan pada sistem sensoris yang akan menyebabkan ketidaksesuaian referensi internal (vestibuler) dengan referensi eksternal (visual dan proprioseptif) sehingga menyebabkan konflik sensoris. Konflik tersebut menyebabkan prerepsi yang tidak akurat terhadap gerakan sehingga akan menyebabkan jatuh. Konflik sensoris ini akan disesuaikan oleh sistem saraf pusat hingga tingkat tertentu, tujuannya untuk mengembalikan homeostasis pada sistem vestibular sentral. Kemampuan tersebut akan menyebabkan integrasi yang awalnya dipresepsikan sebagai sinyal abnormal akan menjadi normal. Proses penyesuaian ini dikenal sebagai kompensasi vestibuler. Ada 2 fase kompensasi vestibuler yaitu fase kompensasi statis dan fase kompensasi dinamik. Pada fase kompensasi statis terjadi penyeimbangan kembali dari aktivitas basal nukleus vestibularis untuk meminimalisir ketidaksesuaian antara laju stimulus sisi kanan dan kiri dari neuron tingkat dua pada nukleus vestibularis sedangkan mekanisme kompensasi vestibuler dinamis terdiri dari adaptasi, habituasi dan subtitusi. ${ }^{13}$

Penambahan Cawthorne Cooksey Exercise (CCE) pada senam lansia secara bertahap melatih otot mata dan tubuh untuk menggunakan visual dan sinyal proprioseptif untuk mengkompensasi sinyal vestibular yang hilang atau terganggu pada lansia yang mengalami penurunan sistem keseimbangan dengan mekanisme adaptasi, habituasi, dan substitusi serta meningkatkan sistem muskuloskeletal pada lansia. Gerakan mata dan kepala pada CCE akan merangsang adanya adaptasi vestibular. Adaptasi vestibular adalah kemampuan sistem saraf pusat untuk memodifikasi besarnya respon vestibulo ocular reflex (VOR) yang akan meningkatkan stabilutas pandangan. Mekanisme habituasi akan menyebabkan peningkatan sensitifitas terhadap gerakan kepala atau pergerakan lingkungan visual, tujuannya adalah untuk meningkatkan stabilitas pandangan dan kontrol postural. Dan mekanisme substitusi akan meningkatkan aktivasi refleks serviko-okuler melalui gerakan mata pada latihan CCE, kemudian akan terjadi adopsi stratego alternatif untuk menggantikan fungsi vestibuler yang terganggu. Gerakan tubuh pada posisi duduk dan berdiri akan meningkatkan sistem somatosensoris sehingga pada latihan CCE ini akan meningkatkan integrasi dari sistem visual, vestibular, dan somatosensoris sehingga meningkatkan kontrol postural dan menurunkan risiko jatuh. ${ }^{14}$ Hasil penelitian ini diperkuat oleh penelitian lain yang menyatakan bahwa program CCE dapat menurunkan risiko jatuh pada lansia normal. ${ }^{15}$

\section{Penambahan Cawthorne Cooksey Exercise pada Senam Lansia Lebih Baik dibandingkan Senam Lansia dalam Menurunkan Risiko Jatuh Lansia}

Kedua perlakuan yaitu penambahan CCE pada senam lansia dan senam lansia telah dibuktikan melalui penelitian bahwa dapat menurunkan risiko jatuh. Tetapi dengan penambahan CCE pada senam lansia memiliki hasil yang lebih baik dalam menurunkan risiko jatuh, karena CCE memberikan pengaruh besar kepada sistem vestibular dimana sistem tersebut sebagai pusat keseimbangan tubuh sehingga terjadi peningkatan kontrol postural dan penurunan risiko jatuh pada lansia.

Program CCE dapat menurunkan risiko jatuh pada lansia normal. Proses kompensasi keseimbangan alami tubuh pada program CCE alan meningkatkan plastisitas sistem keseimbangan. Kontrol terhadap posisi tubuh dan orientasi membutuhkan suatu proses koordinasi motorik yang mengatur otot-otot tubuh untuk melakukan pergerakan badan7. Gerakan gerakan tersebut yaitu gerakan kepala tetap yang bergerak hanya mata (Pursuit) dan gerakan kepala horizontal (Saccade) akan menstimulus sistem vestibular dan visual yang berperan sebagai faktor internal dalam keseimbangan. Gerakan yang bervariasi tersebut akan menjaga koordinasi mata dan respon visual. Respon visual memberikan stimulus ke susunan sarat pusat mengenai posisi tubuh terhadap kondisi lingkungan sekitar dan kondisi bagian tubuh yang mennyebabkan peningkatan kesiagaan postural dengan lingkungan. Pada senam lansia, peningkatan keseimbangan terjadi pada sistem muskuloskeletal, Senam lansia merupakan aktivitas fisik yang baik untuk meningkatkan fungsi otot dan sendi, apabila otot sering dilatih akan meningkatkan cairan sinovial dalam sendi yaitu pelumas dalam sendi sehingga dapat mengurangi risiko cidera pada lansia. ${ }^{16}$

Perbedaan prinsip latihan mengakibatkan perbedaan perbaikan. Pada kelompok perlakuan dengan penambahan CCE pada senam lansia terjadi perbaikan yang dominan pada pusat keseimbangan (sistem visual, vestibular, dan somatosensoris) dan tingkat perifer (sistem muskuloskeletal). Sedangkan pada senam lansia saja dominan terjadi perbaikan tingkat perifer yaitu pada sistem muskuloskeletal, sehingga pada penambahan CCE pada senam lansia akan menghasilkan penurunan risiko jatuh yang lebih baik dibandingkan senam lansia saja.

\section{SIMPULAN}

Berdasarkan hasil penelitian, maka dapat disimpulkan bahwa:

1. Senam lansia dapat menurunkan risiko jatuh pada lansia di Karang Lansia Melati Putih Jembrana yang dilihat dari rerata peningkatan skor BBS yaitu 35,83 menjadi 40,33 atau sebesar $12,5 \%$.

2. Penambahan Cawthorne Cooksey Exercise pada senam lansia dapat menurunkan risiko jatuh pada lansia di Karang Lansia Melati Putih Jembrana yang dilihat dari rerata peningkatan skor BBS yaitu 36,83 menjadi 43,17 atau sebesar $14,68 \%$.

3. Penambahan Cawthorne Cooksey Exercise pada senam lansia lebih efektif dibandingkan senam lansia dalam menurunkan risiko jatuh lansia di Karang Lansia Melati Putih Jembrana. 


\section{DAFTAR PUSTAKA}

1. Republik Indonesia. Undang Undang No. 13 Tahun 1998 Tentang Kesejahteraan Lansia. Jakarta: Sekretariat Kabinet RI; 1998

2. Badan Pusat Statistik. Statistik Penduduk Lanjut Usia 2019. Badan Pusat Statistik. Jakarta: Badan Pusat Statistik; 2019.

3. Kemenkes RI, 2014. Situasi dan Analisis Lanjut Usia. Jakarta: Pusat Data dan Informasi.

4. Lord SR, Smith ST, Menant JC. Vision and falls in older people: risk factors and intervention strategies. Clinics in geriatric medicine. 2010;26(4):569-81.

5. WHO. WHO Global Report on Fall Prevention in Older Age. WHO Library Cataloguing-in-Publication Data. 2007.

6. Ariawan IY, Kuswardhani RT, Astika IN, Aryana IG. Hubungan antara activities specific balance confidence scale dengan umur dan falls pada lansia di poliklinik geriatric RSUP Sanglah Denpasar. Jurnal Penyakit Dalam. 2011;12(1):34-7.

7. Lengkong G, Marunduh SR, Wungow HI. Pengaruh senam bugar lansia terhadap kebugaran jantung paru di Panti Werdha Bethania Lembean. eBiomedik. 2016 Nov 1;4(2).

8. Schubert MC, Whitney SL. From Cawthorne-Cooksey to biotechnology: where we have been and where we are headed in vestibular rehabilitation?. Journal of Neurologic Physical Therapy. 2010;34(2):62-3.

9. Susilo W, Limyati Y, Gunawan D. The Risk of Falling in Elderly Increased with Age Growth and Unaffected by Gender. Journal of Medicine and Health. 2017;1(6).

10. Azizah FD, Sari YM. Hubungan Antara aktivitas fisik dengan resiko jatuh pada lanjut usia di desa jaten kecamatan juwiring klaten. Universitas Muhammadiyah Surakarta; 2017.

11. Pristianto A, Adipura N, Irfan M. Perbandingan Kombinasi Bergantian Senam Lansia Dan Latihan Core Stability Dengan Hanya Senam Lansia Terhadap Peningkatan Keseimbangan Statis Lansia. Sport and Fitness Journal. 2016;4(1):1-5.

12. Manangkot MV, Sukawana IW, Wita IM. Pengaruh senam lansia terhadap keseimbangan tubuh pada lansia di lingkungan Dajan Bingin Sading. J Keperawatan Community of Publishing Nursing. 2016;4(1):24-7.

13. Fransisca IA, Haris ME. Peranan Terapi Rehabilitasi Vestibular dalam Penatalaksanaan Presbiastasis. Jurnal THTKI. 2012;5(2):101-113.

14. Kaesler DS, Mellifont RB, Kelly PS, Taaffe DR. A novel balance exercise program for postural stability in older adults: a pilot study. Journal of Bodywork and Movement Therapies. 2007;11(1):37-43.

15. Khurana N, Gaur DK, Linjhara S. Effect of Cawthorne and Cooksey exercises on balance in elderly and risk of fall. Indian Journal of Gerontology. 2015;29(4):398-406.

16. Suhartati C, Asnindari LN. Perbedaan Risiko Jatuh pada Lanjut Usia yang Mengikuti Senam dengan yang Tidak Mengikuti Senam di PSTW Yogyakarta Unit Budi Luhur. STIKES Aisyiyah Yogyakarta; 2014. 